\title{
Ratlarda Skrotal Ekstrakutan ve Ensizyonel Subkutan Ligatür Uygulamasının ve Etkilerinin Değerlendirilmesi $*, * *$
}

\author{
Cafer Tayer işLER ${ }^{1, a, * * *}$, Ahmet UYAR ${ }^{2, b}$, Tuğba GÖKALP BOZAN ${ }^{3, c}$ \\ ${ }^{1}$ Hatay Mustafa Kemal Üniversitesi, Veteriner Fakültesi, Cerrahi Anabilim Dalı, Hatay, Türkiye \\ ${ }^{2}$ Hatay Mustafa Kemal Üniversitesi, Veteriner Fakültesi, Patoloj Anabilim Dalı, Hatay, Türkiye \\ ${ }^{3}$ Batman Belediyesi Veteriner İşleri Müdürlüğü, Batman, Türkiye \\ aORCID: 0000-0002-1910-8316, 'ORCID: 0000-0003-4345-6756, 'ORCID: 0000-0002-0696-253X
}

Geliş Tarihi: 20.09. 2019

Kabul Tarihi: 05 . 12. 2019

\begin{abstract}
Özet: Bu çalışma; sokak hayvanlarının üremelerinin kontrol altına alınmasına katkıda bulunmak amacıyla yapıldı. Bu amaçla yapılan invaziv veya noninvaziv uygulamaların hem başarısını arttırmak hem uygulama süreçlerini kısaltmak hem de masraflarını minimize ederek hayvan refahına olan etkilerini en aza indirmek için insani ve komplikasyonsuz bir metot geliştirmek planlanmıştır. Bu çalışmada 20 adet erkek rat kullanıldı. Ratlar onarlı iki eşit gruba ayrıldı. Gruplardan birine skrotal ekstrakutan diğerine ensizyonel subkutan ligatür uygulaması yapılarak iki ayrı teknikle kastrasyon uygulaması gerçekleştirildi. Deney hayvanlarına operasyon sonrası 3 gün antibiyotik uygulaması yapıldı ve 10 gün boyunca skrotal değişiklikler kliniksel olarak kontrol edildi. Histopatolojik incelemelerde testis dokusunun komple nekroze olduğu gözlendi. Her iki tekniğin de kastrasyon işleminde başarılı bir şekilde kullanılabildiği ortaya konuldu. Sonuç olarak ratlarda skrotal ekstrakutan ve enzisyonel subkutan ligatür uygulamasının kastrasyon için başarılı olduğu, uygulamanın pratik ve etkili olduğu, kliniksel olumsuzlukların bulunmadığı, masraflı, komplikasyonlu ve ağır anestezik uygulamalara gerek olmadığı belirlendi. Ekstrakutan ve subkutan ligatür ile kastrasyonun sokak hayvanlarında ve pet hayvancılığında üremenin kontrol altına alınmasında uygulaması kolay, pratik, başarılı ve alternatif bir çözüm olacağı, serbest veteriner hekimler ve Belediye Veteriner İşleri Müdürlüklerinin başarısını arttıracağı, toplumsal bir soruna pratik bir çözüm olacak yeni teknikler olarak tavsiye edilmektedir.
\end{abstract}

Anahtar Kelimeler: Kastrasyon, Rat, Sokak hayvanları, Ligatür.

\section{Evaluation of Scrotal Extracutaneous and Incisional Subcutaneous Ligature Application and Its Effects in Rats}

\begin{abstract}
This study was conducted to contribute to the control of the reproduction of stray animals. For these reasons, it was planned to developed a humanitarian and un-complicated method in order to increase the success of invasive or noninvasive applications, to shorten the time of application processes, and to minimize the effects on animal welfare by reducing the costs. In this study, 20 male rats were used. The rats were divided into two equal groups. Two different castration techniques were performed: scrotal extracutaneous to one group and incisional subcutaneous ligature to another group. Antibiotics were applied to the rats postoperatively for three days and scrotal changes were checked clinically for 10 days. Histopathological examination revealed complete necrosis of testicular tissue. Both techniques were found to be successful in castration. In conclusion, scrotal extracutaneous and incisional subcutaneous ligature administration was found to be successful, practical and cost-effective for castration of rats, no clinically undesirable complications and did not require heavy anesthetic applications. Furthermore, these two methods are recommended as an new method to private veterinarians and Municipal Veterinary Affairs Directorate for the castration of stray and pet animals.
\end{abstract}

Keywords: Castration, Rat, Street animals, Ligature.

\section{Giriş}

Tıp diliyle kastrasyon (bilateral orşiektomi); memeli erkeklerinin üreme ve cinsel faaliyette bulunma yeteneğinin ortadan kaldırılması işlemidir (Root Kustritz, 2012). Bu işlem sperm üretimini ve testosteron hormonu salgısını ortadan kaldırarak erkek cinsiyetine özgü yapısal ve davranışsal özelliklerin değişmesine yol açar (Cheney, 2006; Driel, 2009; Halidi, 2017)). İnsanlık tarihi kadar eski, yararlı ve önemli bir operatif teknik olan kastrasyon günümüzde en sık kullanılan metotların başında yer alır (Sarıerler ve Bellek, 2015). Hayvan için daha sağlıklı, toplum içinse daha yararlı olan kastrasyon yöntemleri tarihin birçok devrinde gündem oluşturmuştur (Salmeri et al., 1991, Samsar, 1978; Sarıerler ve Bellek, 2015). Son zamanlarda sokak hayvanlarının artışıyla beraber kastrasyonun önemi daha da belirginleşmiştir (Günay ve ark., 2004). Kastre edilmeyen hayvanlar birbirleri arasında 
hastalıkların yayılmasına yol açmakta, saldırgan olmakta, istenmeyen gebelikler şekillenmekte ve toplumun huzurunu bozmaktadır. Bu nedenlerle kastrasyon, sokak hayvanlarının kontrolsüz üremelerinin önüne geçilmesinde önemli bir yer teşkil eder (Baran ve ark., 2016). Sokak hayvanlarının artışı ile beraber hayvan ve toplum sağığı için cerrahi olmayan kastrasyon teknikleri geliştirilmeye çalışılmaktadır. Kısırlaştırmaya ilişkin endikasyonlar, verimli çiftleşmenin önlenmesi, davranış problemlerinin tedavisi ve testisleri veya skrotumu içeren üreme hastalığının önlenmesini içerir (Donnelly ve Brown, 2004; Reichler, 2009; Spain ve ark., 2004).

Kastrasyon şirurjikal ve nonşirurjikal olmak üzere iki teknikle gerçekleştirilmektedir (Baran ve ark., 2016; Sarıerler ve Bellek, 2015). Şirurjikal ve nonşirurjikal teknik başlığı altında birbirinden farklı pekçok teknikler bildirilir. Bu tekniklerin birkaç tanesi hariç çoğunluğu, arzu edilen faydaları oluşturmadığı için klinisyenler tarafından kullanılmamaktadır. Şirurjikal kastrasyon cerrahi prensiplerle yapılan işlemdir (Bakır ve ark., 2006). Cerrahi kastrasyon; skrotal, preskrotal ve abdominal kastrasyon diye alt grupları halinde uygulanmaktadır (Guilmette ve ark., 2015).

Kastrasyon için yeni teknikler aramaya devam edilse de cerrahi teknikler yerini korumaktadır (Hove, 2006; Samsar, 1978; Towle, 2012). Şirurjikal kastrasyonlar için pek çok metotlar uygulanabilir. Bu amaçla; kapalı ve açık, perineal veya preskrotal kastrasyon (Fossum, 2007; Sarıerler ve Bellek, 2015; Temizer, 1982), açık ya da laparoskopik teknikle vazektomi (Nabi, 2015), sadece funikulus spermatikus'un ligasyonu (Baba ve ark., 2013; Fazili ve ark., 2009) veya arter, ven ve funikulus spermatikus gibi yapıların hep birlikte ligatürü olarak ifade edilen spermatik kord ligaturü (OkweeAca ve ark., 2008; Ponvijay, 2007), funikulus spermatikusun skrotumla birlikte veya subkutan ligaturü, ductus deferensin ligaturü, funikulus spermatikus ligatürünü takiben testisin eksizyonu gibi yöntemleri bildirilmiştir (Abd-el wahed ve ark., 2014; Temizer, 1982).

Cerrahi olmayan kısırlaştırma teknikleri ise; immunokastrasyon (immunokontrasepsiyon, immunosterilizasyon), endojen steroid hormonlarının kullanımı, reprodüktif toksinler, kimyasal sterilizan enjeksiyonlar (Ataman ve Türk, 2016, Hopkins ve Evans, 2003; Maenhoudt ve ark., 2014; Polat ve ark., 2018), 3-19 W ultrason ultrason enerjisi verilmesi gibi (İzol ve ark., 2013) non-invaziv mekanik yöntemler bildirilmiştir (İzol ve ark., 2013). Kimyasal kastrasyon olarak; sıcak uygulama, gliserol ile kastrasyon, etanol ile kastras-yon, çinko glukonat ile kastrasyon, Kalsiyum Klorür $\left(\mathrm{CaCl}_{2}\right)$ ile kastrasyon, formaldehit ile kastrasyon teknikleri kullanılmaktadır (Baran ve ark., 2016; Günay ve ark.,
2004; Hamman ve ark., 2011; Howe ve ark., 2001; Howe, 2006; İol ve ark., 2013).

Türkiye Cumhuriyeti Tarım ve Orman Bakanlığı DKMP Genel Müdürlüğü 2019 mart ayında ülkede bulunan üniversitelerindeki Veteriner Fakültelerinden bir komisyon oluşturarak kastrasyon için ekonomik ve pratik yöntemlerin belirlenmesine yönelik çalışmalar talep etmiştir. Bu çalışma ile, sokak hayvanları ile mücadelede ve pet hayvancılı-ğında rahat, minimal masraflı, noninvaziv, hayvan refahına en az etkili, insani ve komplikasyonsuz bir metot geliştirmek amaçlanmıştır.

\section{Materyal ve Metot}

Çalışma için HMKÜ Hayvan Deneyleri Yerel Etik Kurulu 2018/1-9 nolu kararı ile etik kurul izni alınmıştır. Çalışmada yaşı 8-9 aylık olan, 330-400 gr canlı ağırlıktaki, 20 adet erkek rat; Hatay Mustafa Kemal Üniversitesi (HMKÜ) Deneysel Uygulama ve Araştırma Merkezinden temin edildi. Ratlar onarlı iki gruba ayrıldı ve $10 \mathrm{mg} / \mathrm{kg}$ doz hesabı ile xylazine sedasyonu altında, kastrasyon işlemine tabi tutuldular. Kastrasyon işlemi; iki ayrı ligatür tekniğinin uygulanması ile gerçekleştirildi. Uygulama sonrası 10 gün deneklerin kliniksel ve skrotal değişiklikleri makroskopik olarak günlük kontrol edildi.

1. Grup: Ensizyonel Subkutan Ligatür Uygulaması: Sedasyon altındaki 10 tane ratta skrotal derinin traş ve temizliği yapılarak, bölgenin tentürdiyot ile antisepsisi sağlandı. Her iki testis ve funikulus spermatikus palpasyonla tespit edildi. Palpe edilen testisler abdomene kaçmaması için, bir yardımcı vasıtası ile tutuldu. Aseptik malzemelerle antisepsi eşliğinde raphe skroti üzerinden $2 \mathrm{~mm}$ 'lik tam deri ensizyonu uygulandı. Ensizyon hattından 2/0 emilebilen $2 / 3$ eğri nontravmatik cerrahi iğneli polyglycolic acid (PGA) iplik vasıtası ile spermatik kordu içine alan subkutan spermatik kord ligatürü uygulandı ve cerrahi düğüm atıldı. Grubun yarısı uygulama sonrası üçüncü gün testislerdeki hasarın kalıcılığını görmek için cerrahi usul kastrasyon ile kastre edilerek testisler patoloji labaratuvarına gönderildi. Grubun diğer beş üyesi on gün boyunca skrotal değişiklikler makroskopik olarak günlük kontrol edildi. On gün sonunda bu üyeler de cerrahi usulde kastre edilerek histopatolojik incelemeye gönderildi.

2. Grup: Extrakutan Çift İplikli Transfiksiyon Ligatürü Uygulaması: Birinci grupta olduğu gibi rutin işlemler yapıldıktan sonra çift iplikli transfiksiyon ligatürü uygulaması için, skrotum derisi ensize edilmeden, skrotuma raphe skroti üzerinden, anterio-caudal yönlü ve tüm anatomik katları içine alacak şekilde $1 / 3$ eğri travmatik cerrahi sutur iğnesi girildi. Bir makas vasıtası ile iğnenin 
iplikler ile irtibatı kesilerek çift iplik elde edildi. ipliklerin biri sağ, diğeri sol testisi içine alacak şekilde, skrotal ekstrakutan transfiksiyon ligatürü uygulandı. Cerrahi düğümler atılarak işlem tamamlandı. Ligatür sonrası işlemler ilk gruptaki işlemlerin aynı şekli ile yapıldı (Şekil 1-A-D).

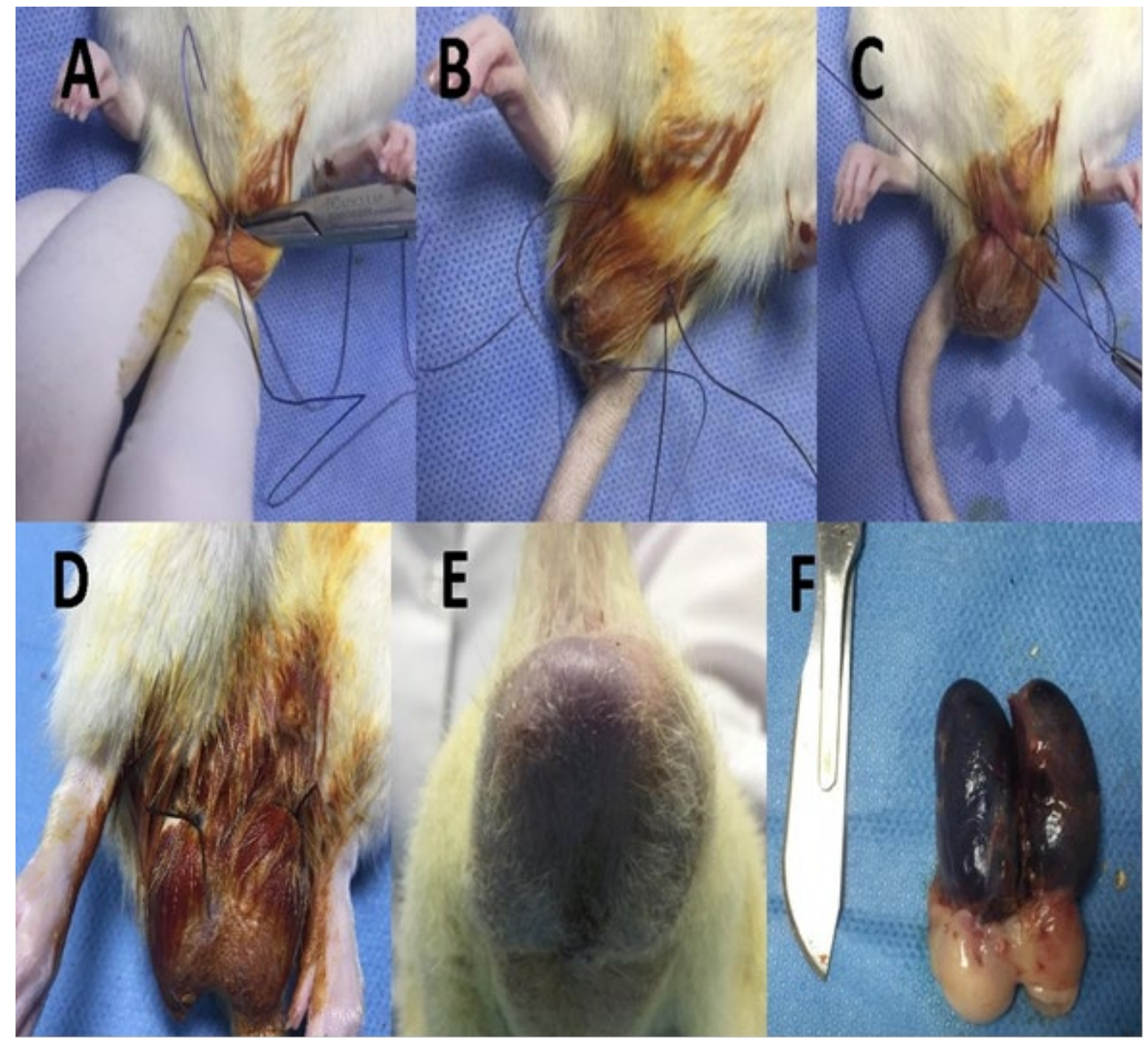

Şekil 1. Ekstrakutan çift iplikli ligatür uygulaması A-iğnenin skrotuma batırıışı. B- Ligatür uygulaması için skrotumda çift ipliğin görünümü. C-Çift iplikle ligatür uygulaması. D- Uygulama sonrası görünüm. E- Uygulama sonrası 3. gün görünümü. F- 10 gün sonra alınan testislerin görünümü

Histopatolojik inceleme: Deneme sonunda tüm hayvanların nekropsileri yapılarak testislerde gözlenen makroskobik bulgular kaydedildi. Histopatolojik inceleme için testislerden alınan doku örnekleri \%10'luk tamponlu formaldehit solisyonunda fikse edildi. Rutin doku takip işlemleri, dehidrasyonları, şeffaflandırılmaları yapılarak parafinde bloklandı. Parafin bloklardan mikrotomda (Leica RM 2135) $5 \mu \mathrm{m}$ kalınlığında kesitler alınarak Hematoksilen-Eozin (H.E.) ile boyanarak ışık mikroskobunda (Nikon 80i-DS-Ri2) incelendi.

\section{Bulgular}

Ratlar, uygulama öncesi ve sonrası kontrol altında tutuldu. Her iki gruptaki deneklerin uygulama öncesi ve sonrası sağlık durumları, yemeiçme ve sosyal davranışları, şekillenebilecek olası değişiklikler, klinik semptomlar veya patolojik bulgular takip altına alındı.

1. Grup: Ensizyonel Subkutan Ligatür Uygulaması: $\mathrm{Bu}$ gruptaki ratlarda uygulama sonrası birinci gün yeme içmede azalma ve yatma isteği gözlendi. Illk 24 saatte hareketlilik uygulama öncesine göre oldukça azdı. Uygulamayı takiben üç saat içinde testislerde lokal şişlik ve ödemleşmenin başladığı gözlendi. Ödem iki gün arttı ve testis normal hacminin iki üç katına ulaştı. Ödemleşen bölgede tüm bölgeyi içermeyen, lokal renk değişikliği -morarmaşekillenmeye başladı. Ödem ve morarma 24. saatte tam belirgin hale geldi. İkinci günden sonra ödem ve morarmada azalma başladı. Deri normal rengini almaya ve şişkinlik inmeye başladı. Onuncu günde 
morarmanın eseri miktarda kaldığı, şişkinliğin önemli oranda azaldığı, ancak testisin anatomik büyüklüğünün normal sınırlara inmediği gözlendi. Uygulama sonrası şekillenen yeme içme alışkanlıklarında değişiklik ve hareketsizlikleri 25 . saatten sonra azalmaya başladığı, 32. saate ise normale döndüğü gözlendi. Bu geçici semptomun haricinde 8 gün süresince yeme içme alışkanlıklarında değişiklik, ağrı, kaşınma, bölgeyi ısırma, huzursuzluk, kanama, saldırganlık, durgunluk veya düşkünlük gibi bir belirtiye rastlanılmadı. Uygulamanın hayvan refahını minimal etkilediği ve enfeksiyon şekillenmediği belirlendi.

2. Grup: Extrakutan Çift İplikli Transfiksiyon Ligatürü Uygulaması: Uygulama sonrası bu grupta da ilk bir gün yeme içmede azalma ve yatma isteği gözlendi. İlk 24 saatte hareketliliğin önemli oranda azaldığı, testiste üç saat içinde ödematöz şişkinliğin şekillendiği gözlendi. Ödematöz şişkinlik 24. saat sonunda testisin normal hacminin iki üç katına ulaştığı belirlendi. Ödemleşen skrotum derisinde lokal morarma gözlendi. Ödem ve morarmanın 24 . saatten sonra gerileyerek rezorbe olmaya başladığı tespit edildi. Onuncu günde morarmanın büyük oranda kaybolduğu, şikinliğin azaldığı ancak normal sınırlara dönmediği gözlendi. Uygulama sonrası şekillenen yeme içme alışkanlıklarında değişiklik ve hareketsizlik tercihleri uygulama sonrası birinci gün düzelmeye başladığı, 32. saate ise normale döndüğü gözlendi. Bu geçici semptomun haricinde 8 gün süresince yeme içme alışkanlıklarında değişiklik, ağrı, kaşınma, bölgeyi ısırma, huzursuzluk, kanama, saldırganlık, durgunluk veya düşkünlük gibi bir belirtiye rastlanılmadı. Uygulamanın hayvan refahını fazla bir etkisi olmadığı, enfeksiyon şekillenmediği belirlendi.

Histopatolojik Bulgular: Makrosbobik incelemede, uygulama sonrası üçüncü güne ait numunelerde, şiddetli testiküler iskemi nedeniyle bütün skrotal bölgenin ve testislerin renginin morardığı görüldü (Şekil 1 E, F). Denemenin 3. günü her iki grupta histopatolojik olarak testislerde tubulusların bazal membranın germinatif epitelden ayrılmaya başladığı, seminifer tubul yapısının kısmen bozulduğu ve bazılarında spermatogenetik hücrelerin azaldığı, dejenere olan spermatojenik hücrelerde vakuolizasyonların şekillendiği, bazı tubulusların atrofiye olmaya başladığı, tubuluslar arası aralığın açıldığı, leydig hücrelerini de içeren interstisyel yapılarda dejenerasyon ve nekrozların başladığı ve yer yer interstisyumda hiyalizasyonun şekillendiği görülmüştür (Şekil 2 ve şekil 3). Denemenin 10.gününe ait kesitlerde her iki grupta da nekrozun şekillendiği, tubulusların çok şiddetli atrofiye oldukları, atrofiye olan birtakım tubulusların lize olduğu, genellikle peritubuler olmak üzere interstisyumda yer yer inflamatuar hücre infiltrasyonlarına rastlandığı, spermatogenezisin tamamen durduğu, germinatif epitel ve leydig hücreleri de dahil interstisyel yapılarının nekroza uğradığı, nekrotik bölgelerin distrofik kalsifikasyona uğradığı, interstisyumda yoğun hemosiderin pigmentinin şekillendiği belirlenmiştir (Şekil 4 ve şekil 5).

\section{Tartışma ve Sonuç}

En yaygın kısırlaştırma yöntemi bilateral orşiektomidir. Hızlı yağlanmaya ve tembelleşmeye neden olduğundan, cerrahi kastrasyonun zorunlu olduğu haller dışında tercih edilmemelidir. Sokaktaki kedi ve köpek popülasyonlarını kontrol altına almak için kalıcı kısırlaştırma yani cerrahi kastrasyon, pahalı ve zaman alıcı bir uygulamadır. Günümüzde cerrahi kısırlaştırmaya farklı alternatif yöntemler araştırılmaktadır (Baran ve ark., 2016). Bilateral orşiektomi, uygulama olarak, zaman alıcı ve operatif bir girişimdir. İlaç ve ameliyat gibi masrafları dolayısı ile pahalı, anestezi risk ve komplikasyanları nedeni ile sıkıntılara yol açabilen bir metottur. Araştırmamızda skrotal ekstrakutan ve ensizyonel subkutan ligatür uygulaması ile sokak hayvanları sorununa pratik ve ekonomik çözüm sunmak amaçlanmış, çalışma sonunda testislerin tamamen nekroze olduğu için oldukça başarılı, uygulaması kolay, etkili ve ekonomik olduğu belirlenmiştir.

Cerrahi olmayan kastrasyon uygulamaları, intratestiküler ya da intraepididimal kimyasal enjeksiyon uygulamaları şeklinde yapılmaktadır (Ataman ve Türk, 2016; Türk ve ark., 2004). Testis içine enjekte edilen çeşitli kimyasal maddeler erkek hayvanlarda azospermi'yi uyararak infertiliteye neden olmaktadır. Nonşirurjikal kastrasyon ucuz ve başarılıdır. Bu işlem için erkek köpeklerde sedasyon, erkek kediler de ise genel anestezi yeterli olmaktadır (Bakır ve ark., 2006). Araştırmamızda skrotal ekstrakutan ve ensizyonel subkutan ligatür uygulaması kastrasyonun tüm etkilerini irreversibl olarak yerine getirdiği, kastrasyonda alternatif ve başarılı bir yöntem olduğu belirlenmiştir.

Nonşirurjikal kısırlaştırma amacıyla androjenler, progestagenler, anabolik steroidler, antiandrojenler ve $\mathrm{GnRH}$ (gonodotropin releasing hormon) antagonistleri yaygın olarak kullanıldığı, ancak bu hormonlar iyi bir azospermi oluşturmalarına rağmen etkileri sürekli olmadığından uygulamanın tekrarına gerek duyulduğu bildirilmiştir (Anand ve Vijayan, 1998; Gerendai ve ark., 1996; Günay ve ark., 2004, Theubet ve ark., 2010). İlaç tekrarını hayvanın hem sağlığı hem de masraf yönünden önemli bir dezavantaj olarak görmekteyiz. Özellikle sokak hayvanlarında ilaç tekrarı da mümkün değildir. 


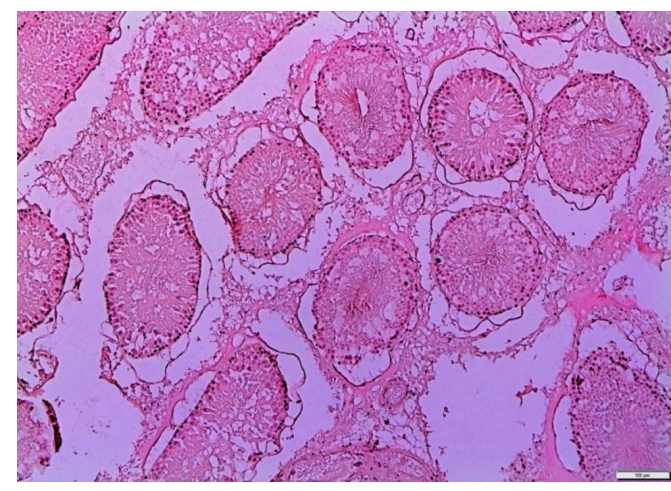

Şekil 2. Ensizyonel subkutan ligatür uygulaması grubu 3. gün testis dokusunun mikroskobik görünümü. $\mathrm{HE}$, bar: $100 \mu \mathrm{m}$

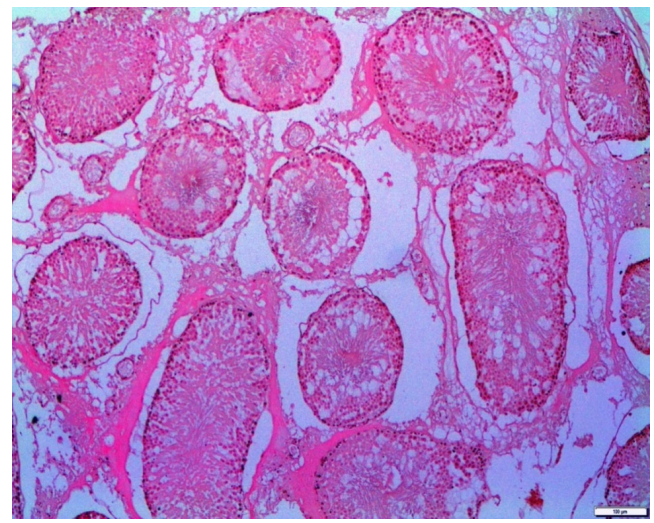

Şekil 3. Extrakutan çift iplikli transfiksiyon ligatürü uygulaması grubu 3. gün testis dokusunun mikroskobik görünümü. $\mathrm{HE}$, bar: $100 \mu \mathrm{m}$.

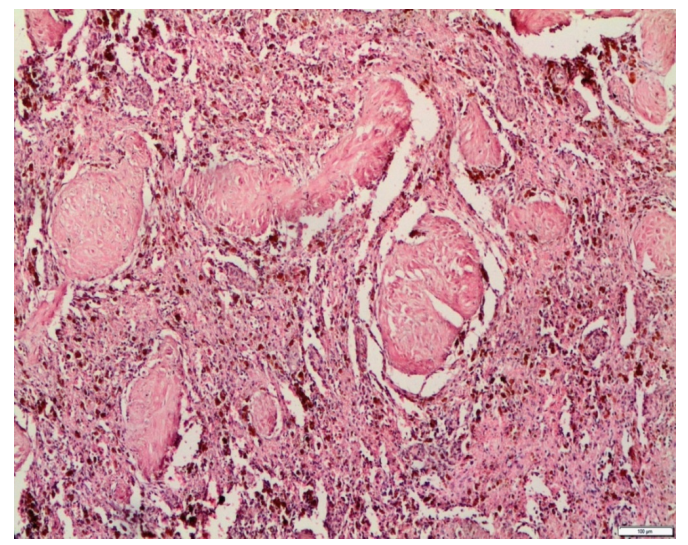

Şekil 4. Ensizyonel subkutan ligatür uygulaması grubu 10. gün testis dokusunun mikroskobik görünümü. HE, bar: $100 \mu \mathrm{m}$.

Zira bu hayvanlar barınaklarda uzun süre tutulmamakta, sokak ortamına gönderilmektedirler. Kaldı ki kullanılan ilaçların çoğu hormon olduğu ve bağışıklık sistemini önemli oranda etkilediği için obeziteden salgın hastalıklara kadar pekçok yan etki ve komplikasyonları mevcut-tur. Araştırmamızda uygulanan skrotal ekstrakutan ve ensizyonel subkutan ligatür uygulaması kastrasyonun tüm etkilerini irreversibl olarak yerine getiren ekonomik ve pratik bir tekniktir. Masrafı, komplikasyonu, yan etkisi az, kesin çözümdür.

Etil alkolün \% 95'lik (Chinoy, 1984; Sharma ve ark., 1983), kalsiyum kloridin (Jana ve ark., 2002),

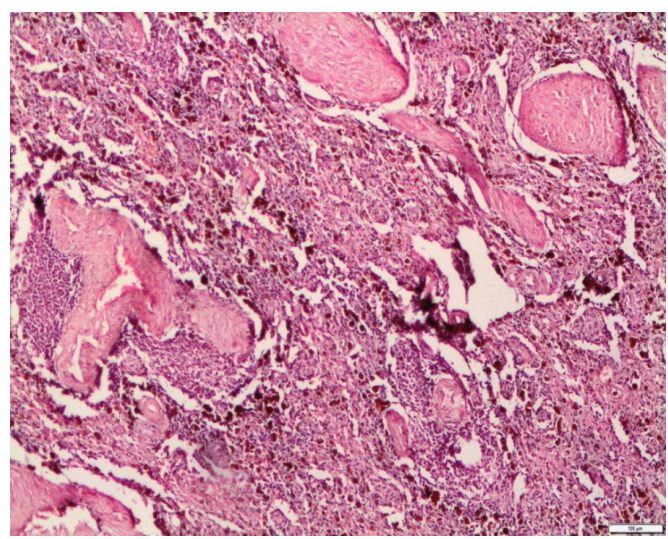

Şekil 5. Extrakutan çift iplikli transfiksiyon ligatürü uygulaması grubu 10. gün testis dokusunun mikroskobik görünümü. $\mathrm{HE}$, bar: $100 \mu \mathrm{m}$.

sodyum floridin (Sprondo ve ark., 1996), etanol'ün (Canpolat ve ark., 2006; Raman ve ark., 1976;) tubulus seminiferus kontortuslarda dejenerasyon ve nekroza yol açarak spermatogenezisi durdurduğu ve leydig hücrelerinde de dejenerasyona neden olarak serum testosteron seviyesini düşürdüğü ancak kullanılan ilacın özelliğine, dozuna, çevre dokulara yayılmasına bağlı olarak prostatit, üriner sistem nekrozu ve yangıları, kontrolsüz ürinasyon, idrar kesesi felci gibi komplikasyonlara yol açabileceği bildirilmiştir. Gliserol ve etanol'ün erkek köpeklerde intratestiküler enjeksiyonlarının kısırlaştırma üzerinde etkili olduğu bildirilmiştir (Canpolat ve ark., 2006; Hayat ve Biricik, 2008; Jana ve ark., 2002). Günay ve ark. (2004) ise kalsiyüm klorür, gliserol veya etanol ile yapılan kimyasal kastrasyonda hayvanların testislerinde lokal semptomlar oluştuğunu, uygulamadan sonrası yatma isteği iştahsızlık ve sancı belirtilerinin görüldüğünü, testislerde orşitis ve buna bağlı fistülizasyon, skrotumda açık yaralar şekillendiği, vazektomi yönteminde anestezik risk ve postoperatif komplikasyonların gelişebileceği (Günay ve ark., 2004; Immegart ve Threlfall, 2000), duktus defferensin kimyasal ilaçlarla kapatılması yönteminde (Gerendai ve ark., 1996) ise başarı oranının düşük olacağı bildirilmiştir. Yaptığımız çalışmada lokal şişkinlik ve geçici iştah kaybı haricinde hayvan refahını etkileyen bir duruma rastlanılmadı. Hatta nekroze testisin irinleşme ve fistülleşmeye yol açması mümkün iken bu ihtimalin şekillenmediği, on gün sonra yapılan cerrahi kastrasyonda nekrotik testis dokusunda maserasyonun başladığı gözlendi. Anestezik risk ve postoperatif komplikasyonların önlenmesi ve kimyasal ilaç ve maddelerin kullanılarak sağlık sorunlarının önüne geçilmesi adına araştırmamızda kullanılan skrotal ekstrakutan ve ensizyonel subkutan ligatür uygulaması kastrasyonun tüm etkilerini komplikasyonsuz olarak yerine getirdiği, diğer doku ve organların hiçbir şekilde etkilenmediği, ağrı veya prostatit, idrar kesesi felci gibi çevre dokuların 
hastalıklarına yol açmadığı, fistül, yara, apse, kontrolsüz idrar kaçırma gibi sekonder hastalıkların ortaya çıkmadığı belirlendi. Tekniğimizin komplikasyonsuz, daha insancıl, daha basit, kolay, kansız, ekonomik ve başarılı olduğu belirlenmiştir.

Sokak köpeklerinde genel anestezi altında perkütan spermatik kord ligasyonu yapıldığı, 28. günde skrotal ve testis boyutları ve testis hacmi değiştiği ve bilateral orşiektomi yapılarak alınan testislerin hacminin önemli oranda azaldığı, erkek köpek sterilizasyonu için minimal invaziv, ucuz, basit ve hızlı bir teknik olduğu Baba ve ark. (2013) tarafından bildirilmiştir. Klinik uygulama ve elde edilen sonuçlar Baba ve ark. (2013)'nın bildirdikleri ile birebir uyumlu iken, çalışmamızda hem makroskobik hem de patolojik olarak testis dokusundaki dejenerasyonun hem 3. hem de 10. günde tespit ettik. Bu durum daha erken sonuca ulaştığımızı ortaya koymuştur. Ayrıca; skrotal ekstrakutan ve ensizyonel subkutan ligatür uygulaması bir enjeksiyon yapacak kadar kolay bir uygulama olup, sedasyona, kimyasal ajana, masrafa ve komplikasyonlara yol açmayacak bir teknik olarak değerlendirilmiştir. Sokak hayvanlarında ekstrakutan ve subkutan ligatür uygulamasının başarılı sonuçlar vereceği düşünülmektedir.

Ülkemizde yerel ve büyükşehir belediyeleri aracılığı ile yürütülen projelerdeki kısırlaştırma metotları fazla ekipman, deneyimli personel ve maddi imkan gerektirmesi, personelin liyakatsizliği, gerek cerrahi gerekse nonşirurjikal yolla ve toplu olarak yapılan kısırlaştırma işlemlerinde istenilen sonuçlar elde edilememektedir (Baran ve ark., 2016). Çalışmamızda uygulanan ligatür tekniğinin her ikisi de pratik, kısa zamanda çok sayıda hayvana uygulanabilmesi, çok az maddi kaynağa ihtiyaç göstermesi açısından gelecekte cerrahi yolla kısırlaştırmaya güçlü bir alternatif olacağı görülmektedir.

T.C. Tarım ve Orman Bakanlığı 2019 Mart ayında resmi yazı ile tüm veteriner fakültelerinden bir komisyon oluşturmuş ve kastrasyon için ekonomik ve pratik yöntemlerin belirlenmesini istemiştir. Bu çalışma; bakanlığın çalışmalarına önemli bir adım ve referans bir kaynak mahiyetindedir. Yani; bu uygulamanın tüm meslektaşlarımıza, akademik camiaya, Tarım Bakanlığı, Belediye Veteriner İşleri Müdürlüklerince uygulanabilir, pratik, ekonomik ve başarılı bir metot olarak tavsiye edilmesi tarafımızca uygun olarak değerlendirlimiştir. Magazin haberlerine konu olan sokak hayvanlarının saldırganlığı ve popülasyonunun kontrol edilememesi toplum hayatı için ciddi bir handikap kaynağı oluşturmakta, büyüyen bir problem olarak karşımıza çıkmaktadır. Hem insan hem hayvan sağlığı açısından potansiyel bir tehlike olan sokak hayvanları zoonoz, viral, parazitolojik, enfeksiyoz birçok hastalığın yayılmasından da sorumludurlar. Bu olumsuzluklar araştırmacıları ve bakanlığı bu konu üzerinde daha çok çalışmaya itmiş ve cerrahi olmayan yollarla testis içi kimyasal kısırlaştırma teknikleri geliştirilme çalışmaları bakanlık kanalı ile yeni başlamıştır.

Ratlarda Scrotal Exracutan ve Ensizyonel Subkutan Ligatür Uygulamasının kastrasyon işlemi için başarılı olduğu, uygulamanın kolay olduğu, ligatürlerin açılması sonucu veya bölgenin ısırılarak veya kaşınarak uygulamanın başarısızlığa düşmesi gibi olumsuzlukların yaşanmadığı, klinik olumsuzluklara yol açmadığı ve ağır anestezik uygulamalara gerek olmadığı belirlendi. Çalışmamızda uygulananan her iki tekniğin kolay, pratik, masrafı yok denecek kadar az olduğu ve irreversibl olarak kastrasyonu işlemini gerçekleşmesi nedeni ile sokak hayvanları ile mücadelede de etkili olacağı kanaatine varıldı.

Sonuç olarak; çalışmamızda uygulanan ligatür tekniğinin her ikisi de pratik olduğu, kısa zamanda çok sayıda hayvana uygulama imkanı sağladığı, ekonomik giderin çok düşük olduğu, bu sebeplerle cerrahi yolla kısırlaştırmaya güçlü bir alternatif olacağı ön görülmektedir.

\section{Kaynaklar}

Adair BM, 1986: Abd-el wahed RE, Korritum AS, Abuahmed HM, Samy AA, 2014: Evaluation of pinhole castration technique compared with traditional method for castration in dogs. Alex J Vet Sci, 42(1), 90-98.

Türk G, Sağlıyan A, Yaman I, Sönmez M, Günay C, 2004: Erkek köpeklerde intratestiküler gliserol ve etanol uygulamalarının kısırlaştırma üzerine etkilerinin karşılaştırılması, Veteriner Cerrahi Dergisi, 10(1-2), 55-60.

Hayat A, Biricik HS, 2008: Atların kastrasyonlarında görülen başılıca komplikasyonlar. Doğu Anadolu Bölgesi Araştırmaları Dergisi, 84-88.

Ataman O, Türk G, 2016: Erkeklerde kullanılan cerrahi ve cerrahi olmayan kontrasepsiyon yöntemleri. Fırat Üniversitesi, Sağ. Bil.Vet. Dergisi, 30(1), $67-73$.

Temizer A, 1982: Evcil hayvanlarda operasyon bilgisi. Firat Üniverstiesi Veteriner Fakültesi Yayınları, 28 (Ders kitabı:10). Ankara Üniversitesi Basımevi.

Driel MV, 2009. Reaktion Books, Manhood: The Rise and Fall of The Penis. English Translate by Vincent $P$, Lon.

Baba MA, Fazili MR, Athar H, Mir MS, Moulvi BA, Khan I, 2013: Pinhole castration technique: an alternative to orchiectomy in stray dogs. Anim Reprod Sci, 137(12), 113-118.

Bakır B, Gülyüz F, Karaca F, Yüksel H, Şahin A, Uslu BA, 2008: Köpekler kimyasal kastrasyon. Yüzüncü Yıl Üniversitesi, Sağlık Bilimleri Dergisi, 9(1), 195-202.

Baran A, Özdaş ÖB, Sandal Ai, 2016: Erkek Kedi ve Köpeklerde Üremenin Önlenmesi.Turkiye Klinikleri J Vet Sci Obstet Gynecol-Special Topics, 2(2), 9-18 
Canpolat I, Gur S, Gunay C, Bulut S, Eroksuz H, 2008: An evaluation of the outcome of bull castration by intra-testicular injection of ethanol and calcium chloride. Revue de Médecine Vétérinaire, 157(8/9), 420.

Cheney VT, 2006: A Brief History of Castration: Second Edition. AuthorHouse. ISBN-13: 978-1420897203.

Chinoy MR, Chinoy NJ, 1984: Vasocclusion Sterility Induced by Ethanol, Prostoglandin or Ascorbic Acid in Male Rats. Endokrinol Exp. 18(1), 65-77.

Donnelly TM, Brown CJ, 2004: Guinea pig and chinchilla care and husbandry. Vet Clin North Am Exot Anim Pract, 7, 351-373.

Fazili MR, Bhattacharyya HK, Buchoo BA, Kirmani MA, Darzi MM, Khan I, 2009: Evaluation of pinhole castration technique in rams. Small Rumin Res, 84, 61-4.

Fossum TW, 2007: Surgery of the reproductive and genital systems. In: Fossum TW, eds. Small Animal Sur- gery. 3rd ed. Missouri: Mosby Inc, 702-74.

Gerendai I, Csaba Z, Csernus V, 1996: Effect of Intratesticular Administration of Somatostatin on Testicular Function in Immature and Adult Rats. Life Sci, 59(10), 859-866.

Guilmette J, Langlois I, Hélie P, De Oliveira El Warrak A, 2015: Comparative study of 2 surgical techniques for castration of guinea pigs (Cavia porcellus). Canadian Journal of Veterinary Research, 79(4), 323-328.

Günay C, Sağlıyan A, Yaman I, Sönmez M, Türk G, 2004: Erkek köpeklerde intratesticular gliserol ve etanol uygulamalarının kısırlaştırma üzerine etkilerinin karşılaştırılması. Veteriner Cerrahi Dergisi, 10(1-2), 55-60.

Halidi G, 2017: Farinelli Örneğinde Kastrasyon. Lokman Hekim Dergisi, 7(3), 215-231.

Hamman WO, Musa SA, Ikyembe DT, Umana UE, Adelaiye AB, Nok, A J, Ojo SA, 2011: Ethanol extract of Carica papaya seeds induces reversible contraception in adult male wistar rats. British Journal of Pharmacology and Toxicology, 2(5), 257-261.

Hopkins M, Evans LE, 2003: Artificial insemination. In: Pineda MH, Dooley MP, eds. McDonald's Veterinary Endocrinology and Reproduction. 5th ed. lowa: lowa State Press.

Howe LM, Slater MR, Boothe HW, Hobson HP, Holcom JL, Spann AC, 2001: Longterm outcome of gonadectomy performed at an early age or traditional age in dogs. J Am Vet Med Assoc, 218(2), 217-221.

Howe LM, 2006: Surgical methods of contraception and sterilization. Theriogenology, 66(3), 500-509.

İzol V, Değer M, Arıdoğan İ, 2013: Erkek kontrasepsiyon yöntemleri. Androloji Bülteni, 15(53), 117-121.

Immegart HM, Threlfall WR, 2000: Evaluation of intratesticular injection of glycerol for nonsurgical sterilization. AJVR, 61(5), 544-548.

Jana K, Samanta PK, Ghosh D, 2002: Dose dependent response to an intratesticular injection of calcium chloride for induction of chemosterilization in adult albino rats. Vet Res Commun, 26(8), 651-673.

Maenhoudt C, Santos NR, Fontbonne A, 2014: Suppression of fertility in adult dogs. Reproduction in Domestic Animals, 49, 58-63.
Nabi G, 2015: An update on male contraception. J Biol Life Sci, 6, 15-28.

Okwee-Acai J, Acon J, Okello-Owiny D, Agwai B, Oloya J, 2008: Evaluation of pinhole castration as an alternative technique for goat sterilization. Bull Anim Health Prod Afr, 56, 299-306.

Polat S, Ozhan O, Parlakpınar H, 2018: Kimyasal kastrasyon (medikal orşiektomi). Inönü Üniversitesi Sağlık Bilimleri Dergisi, 7(2), 56-60.

Ponvijay KS, 2007: Pinhole castration: a novel minimally invasive technique for in situ spermatic cord ligation. Vet Surg, 36(1), 74-9.

Raman G, Purandare TV, Munshi SR, 1976: Sterility induced in male rats by injection of chemical agents into the vas deferens. Andrologia, 8(4), 321-325.

Reichler IM, 2009: Gonadectomy in cats and dogs: a review of risks and benefits. Reprod Dom Anim, 44(2), 29-35.

Root Kustritz MV, 2012: Effects of surgical sterilization on canine and feline health and on society. Reprod Dom Anim, 4(7,4), 214-22.

Salmeri KR, Olson PN, Bloomberg MS, 1991: Elective gonadectomy in dogs: a review. JAm Vet Med Assoc, 198(7), 1183-1192.

Samsar E, 1978: Köpeklerde skrotal kesenin çıkarılmasıyla yapılan kastrasyon. A.Ü. Vet.Fak. Dergisi, 1, 37-47.

Sarıerler M, Bellek CG, 2015: Erkek köpek ve kedilerde cerrahi kastrasyon teknikleri ile kastrasyonun avantaj ve dezavantajları. Turkiye Klinikleri J Vet Sci Obstet Gynecol-Special Topics, 1(3), 52-56.

Anand LN, Vijayan E, 1998: Studies on effect of intratesticular administration of opioid peptides, naloxone or n-acetyl beta-endorphin antiserum on some testicular parameters in rats. Indian J Physiol Pharmacol, 42(1), 107-112.

Sharma JD, Chinoy NJ, Dixit VP, 1983: Fertility control in vas occluded rats and the biochemical effects of ascorbic acid feeding. Exp. Clin. Endocrinol, 82 (3), 337-341.

Spain CV, Scarlett JM, Houpt KA, 2004: Long-term risks and benefits of early-age gonadectomy in cats. J Am Vet Med Assoc, 224(3), 372-9.

Sprondo RL, Black TN, Ames MJ, 1996: Effect of intratesticular injection of sodium fluoride on spermatogenesis. Food Chem Toxicol, 34(4), 377-384.

Theubet G, Thun R, Hilbe M, Janett F, 2010: Effect of vaccination against GnRH (Bopriva ${ }^{\circledR}$ ) in the male pubertal calf. Schweizer Archiv Fur Tierheilkunde, 152(10), 459-469.

Towle HA, 2012: Testes and scrotum. In: Tobias KM, Johnston SA, eds. Veterinary Surgery Small Animal. Set, Missouri: Elsevier Saunders, 1903-1920.

*Bu yayın aynı isimli yüksek lisans tezinden üretilmiştir.

${ }^{* *}$ Bu tez, Mustafa Kemal Üniversitesi Bilimsel Araştırma Projeleri Birimi tarafından 18.YL.038 nolu proje olarak desteklenmiştir.

***Yazışma adresi: Cafer Tayer IŞLER

Hatay Mustafa Kemal Üniversitesi, Veteriner Fakültesi, Cerrahi Anabilim Dalı, Hatay, Türkiye.

e-mail: cafer.isler@gmail.com 